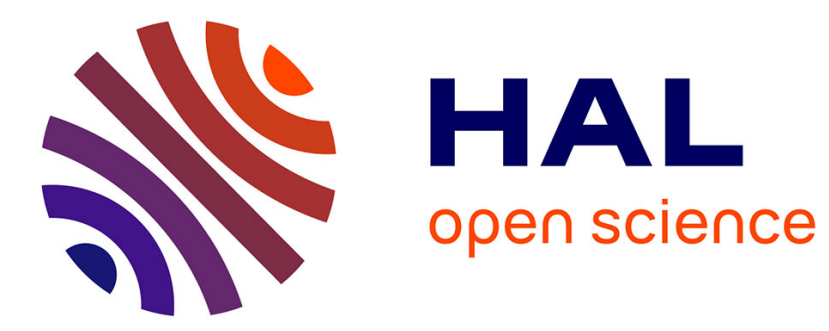

\title{
Thrombotic thrombocytopenic purpura in the first trimester and successful pregnancy
}

Silvia Maria Trisolini, Saveria Capria, Maria Gozzer, Simonetta Pupella, Roberto Foà, Maria Gabriella Mazzucconi, Giovanna Meloni

\section{To cite this version:}

Silvia Maria Trisolini, Saveria Capria, Maria Gozzer, Simonetta Pupella, Roberto Foà, et al.. Thrombotic thrombocytopenic purpura in the first trimester and successful pregnancy. Annals of Hematology, 2008, 88 (3), pp.287-289. 10.1007/s00277-008-0579-4 . hal-00486525

\section{HAL Id: hal-00486525 \\ https://hal.science/hal-00486525}

Submitted on 26 May 2010

HAL is a multi-disciplinary open access archive for the deposit and dissemination of scientific research documents, whether they are published or not. The documents may come from teaching and research institutions in France or abroad, or from public or private research centers.
L'archive ouverte pluridisciplinaire HAL, est destinée au dépôt et à la diffusion de documents scientifiques de niveau recherche, publiés ou non, émanant des établissements d'enseignement et de recherche français ou étrangers, des laboratoires publics ou privés. 


\title{
Thrombotic thrombocytopenic purpura in the first trimester and successful pregnancy
}

\author{
Silvia Maria Trisolini • Saveria Capria • Maria Gozzer • \\ Simonetta Pupella • Roberto Foà • \\ Maria Gabriella Mazzucconi • Giovanna Meloni
}

Received: 28 February 2008 / Accepted: 22 July 2008 / Published online: 7 August 2008

(C) Springer-Verlag 2008

\section{Dear Editor,}

Thrombotic thrombocytopenic purpura (TTP) is a rare complication of pregnancy with a poor prognosis and a high fetal mortality when presenting early during gestation. Few cases of TTP $(10 \%)$ occur during the first trimester [1, 2], the majority occurring at the time of delivery or during post-partum period $[4,6]$. Until the effectiveness of plasma infusion and plasma exchange was recognized, TTP was associated with a mortality rate of $95 \%$ and, in case of pregnancy-related TTP, the maternal survival was rare and the fetal mortality rate approached $80 \%$ [9]. Fetal death is secondary to placental infarction due to thrombotic occlusion of the decidual arterioles [8]. Currently, plasma infusion and plasmapheresis have improved maternal and fetal survival rates [10]. At present, it is well known that termination of pregnancy is rarely needed and that the fetal survival rate could be improved by effective maternal therapy [14]. When TTP occurs during the first trimester of pregnancy and delivery of a viable infant is not an option, plasma exchange treatment is urgently indicated and may allow the pregnancy to continue [13]. There are some reports showing that prolonged courses of plasma exchange, beginning as early as 6 weeks of gestation, may achieve and maintain a remission of TTP allowing delivery of a healthy, full-term infant [1]. When plasma exchange fails to induce remission, therapeutic abortion may be considered, although the response of TTP to termination of

S. M. Trisolini $(\bowtie) \cdot S$. Capria $\cdot$ M. Gozzer $\cdot$ S. Pupella $\cdot$ R. Foà $\cdot$ M. G. Mazzucconi $\cdot$ G. Meloni

Hematology, Dipartimento di Biotecnologie Cellulari ed

Ematologia, "Sapienza" University of Rome,

Via Benevento 6,

00161 Rome, Italy

e-mail: trisolini@bce.uniroma1.it pregnancy is uncertain. We have previously reported a case of a successful pregnancy in a young female who developed a severe TTP relapse at 18 weeks of gestation [5]. In the present study, we describe a case of a first pregnancy concomitant to a severe TTP diagnosed in the first trimester with maternal survival and delivery of a healthy child.

In August 2004, a 26-year-old nulliparous woman at 9 weeks of gestation presenting macrohematuria and ecchymoses was admitted to our institution. Laboratory data showed thrombotic microangiopathy, with anemia $(7.5 \mathrm{~g} / \mathrm{dl})$, thrombocytopenia (platelets $\left.6 \times 10^{9} / 1\right)$, numerous schistocytes $(60 \%)$ in the peripheral blood smears, elevated levels of lactic dehydrogenase (1,472 IU/1 range 70-190) and bilirubin (total $3.4 \mathrm{mg} / \mathrm{dl}$, normal value $0.4-1.1$, indirect $3 \mathrm{mg} / \mathrm{dl}$, normal value $0.1-0.4$ ), reticulocytosis $\left(250 \times 10^{9} / 1\right)$, and negative direct/indirect Coombs' test. Renal function was normal. Bone marrow aspirate showed a normal bone marrow cytomorphology. Thrombophilic screening showed normal levels of antithrombin (AT), absence of lupus anticoagulant (LAC), normal levels of C and $\mathrm{S}$ proteins, and no mutations of Leiden Factor $\mathrm{V}$ and prothrombin gene, while a heterozygous mutation of MTHFR C677T, with normal plasma homocysteine concentrations, was found. Serologic examinations were negative for anti-extractable nuclear antibodies and anticardiolipin antibodies. Unfortunately, ADAMTS-13 levels and inhibitor were not determined during the acute event. On the basis of the symptoms and laboratory tests, a clinical diagnosis of TTP was made and the patient was treated with intravenous methylprednisolone ( $2 \mathrm{mg} / \mathrm{kg} / \mathrm{die}$ to $120 \mathrm{mg} / \mathrm{die})$ and daily plasmapheresis, with plasma replacement of $30 \mathrm{ml} / \mathrm{kg} / \mathrm{die}$, in combination with continuous infusion of fresh frozen plasma (FFP) $(10 \mathrm{ml} / \mathrm{kg} / \mathrm{die})$. Folic acid $(15 \mathrm{mg} / \mathrm{die})$ support was given. The initial response was 
good: after five daily plasma exchanges, the peripheral blood smears showed a decrease in schistocyte count and the platelet count rose to $105 \times 10^{9} / 1$; on day 6 , prophylactic treatment with low-dose aspirin was started $(100 \mathrm{mg} / \mathrm{die})$ together with the infusion of FFP and daily plasmapheresis. On day 11, the laboratory evaluation showed a decrease of platelet count (platelets $\left.46 \times 10^{9} / 1\right)$ and anemia $(7.6 \mathrm{~g} / \mathrm{dl}$ ), with an increase of schistocytosis on peripheral blood smear and reticulocytosis. Aspirin was discontinued and the patient was treated with two doses of intravenous immunoglobulins $(800 \mathrm{mg} / \mathrm{kg} / \mathrm{die}$, days 11 and 16). Plasma exchange was carried out every day. Response to treatment was observed 4 days after the second dose of immunoglobulins, with a decrease in schistocyte count and a progressive increase of the platelets until normalization (more than $150 \times 10^{9} / 1$ ) on day 24 . After complete and stable recovery of the platelets, the doses of steroids were gradually reduced to $1 \mathrm{mg} / \mathrm{kg} / \mathrm{die}$, plasma infusion was discontinued, and plasmapheresis was performed every other day for 2 weeks, then twice weekly for 1 week. After discharge, the patient was submitted to weekly plasma exchange for 1 month, then every 2 weeks until delivery. Methylprednisolone treatment was gradually tapered until $8 \mathrm{mg} /$ die. During hospitalization and subsequently the ultrasonographic examination showed a fetal biometry with harmonious growth. At 35 weeks, the patient had spontaneous contractions and delivered a 2,000 g healthy male baby (Apgar score 9 after $1 \mathrm{~min}$ and 10 after $5 \mathrm{~min}$ ) by cesarean section after epidural analgesia. As prophylactic treatment of venous thromboembolism, low molecular weight heparin (enoxaparin 2,000 IU sc/die) was started after delivery and prolonged for 6 weeks. Prophylactic treatment with dipyridamole was started 2 weeks after cesarean section [3,5]. Steroids were discontinued 10 months after delivery. The patient is in continuous complete remission from TTP 38 months later under prophylactic treatment with dipyridamole. ADAMTS-13 activity is normal.

Despite our successful experience, the issue of optimal management of TTP during pregnancy remains unresolved, especially when it occurs in the first trimester. Very few cases are described in the literature and the disease causes are not known. Some studies have shown that pregnancy may be a risk factor for acute episodes of TTP because of the association of pregnancy with increasing concentrations of procoagulant factors, decreasing fibrinolytic activity, loss of endothelial cell thrombomodulin, and decreasing activity of ADAMTS-13 [6, 7]. All of these abnormalities become progressively more severe through the course of pregnancy until delivery and immediately post-partum; in fact, the majority of cases occurred at this time.

According to the guidelines of the British Committee for Standards in Haematology [14], pregnant patients should be treated with plasma exchange as non-pregnant patients and delivery is recommended only for those women who do not respond to plasmapheresis. Plasma exchange should be continued for several days after normalization of platelets count and resolution of hemolysis is documented $[3-5,9]$. It has now been demonstrated that pregnancy does not impair the response to plasmapheresis and that plasmapheresis does not impair the outcome of pregnancy [3, 4]. Monitoring ADAMTS-13 activity may guide the intensity of therapy, but plasma-responsive TTP may occur in the absence of an overt deficiency of ADAMTS-13. There is considerable evidence that TTP is an immune-mediated disease, due to the presence of both anti-platelet and antiendothelial cell antibodies and inhibitors to the ADAMTS13 [10]. Therefore, it is appropriate to include intravenous immunoglobulin $G$ therapy and glucocorticoids, as prednisone and methylprednisolone, because they do not cross the placenta $[3,4]$ in the management of TTP $[10,11]$. An issue specific for young women is the risk for future pregnancies. Several authors indicate that TTP has an overall relapse rate of $30-60 \%$ and pregnancy may precipitate relapse in women with a history of TTP unrelated to pregnancy; however, the real risk for relapse associated with this condition has not been well documented [5, 8-9]. Women whose initial episode of TTP was idiopathic appear to have a greater risk of recurrence during a subsequent pregnancy compared to women whose initial episode was associated with a pregnancy [12]. With careful counseling and shared assessment of potential risks by the patient and her physicians, and with careful prenatal management, a future pregnancy may be a safe and acceptable decision. These pregnancies should be managed in a care unit where plasmapheresis is available without delaying in the plasma therapy.

\section{References}

1. Rozdzinski E, Hertenstin B, Schmeiser T, Seifried E, Kurrle E, Heimpel H (1992) Thrombotic thrombocytopenic purpura in early pregnancy with maternal and fetal survival. Ann Hematol 64 (5):245-248

2. Mokrzycki MH, Rickles FR, Kaplan AA, Kohn OF (1995) Thrombotic thrombocytopenic purpura in pregnancy: successful treatment with plasma exchange. Case report and review of the literature. Blood Purif 13(5):271-282

3. McCrae KR, Cines DB (1997) Thrombotic microangiopathy during pregnancy. Semin Hematol 34(2):148-158

4. McMinn JR, George JN (2001) Evaluation of women with clinically suspected thrombotic thrombocytopenic purpura-hemolytic uremic syndrome during pregnancy. J Clin Apher 16(4):202209

5. Proia A, Paesano R, Torcia F, Annino L, Capria S, Ferrari A, Ferrazza G, Pacifici E, Penatalissi A, Meloni G (2002) Thrombotic thrombocytopenic purpura and pregnancy: a case report and a review of the literature. Ann Hematol 81(4):210-214 
6. George JN (2003) The association of pregnancy with thrombotic thrombocytopenic purpura-hemolytic uremic syndrome. Curr Opin Hematol 10(5):339-344

7. Ducloy-Bouthors AS, Caron C, Subtil D, Provot F, Tournoys A, Wibau B, Krivosic-Horber R (2003) Thrombotic thrombocytopenic purpura: medical and biological monitoring of six pregnancies. Eur J Obstet Gynecol Reprod Biol 111(2):146-152

8. Castellà M, Pujol M, Julià A, Massague I, Bueno J, Ramon Grifols J, Puig L (2004) Thrombotic thrombocytopenic purpura and pregnancy: a review of ten cases. Vox Sang 87(4):287-290

9. Shamseddine A, Chehal A, Usta I, Salem Z, El-Saghir N, Taher A (2004) Thrombotic thrombocytopenic purpura and pregnancy: report of four cases and literature review. J Clin Apher 19(1):5-10

10. Rock G (2005) The management of thrombotic thrombocytopenic purpura in 2005. Semin Thromb Hemost 31(6):709-716
11. Lampinen K, Peltonen S, Pettila V, Kaaja R (2004) Treatment of postpartum thrombotic microangiopathy with plasma exchange using cryosupernatant as replacement. Acta Obstet Gynecol Scand 83(2): 175-179

12. Vesely SK, Li X, McMinn JR, Terrell DR, George JN (2004) Pregnancy outcomes after recovery from thrombotic thrombocytopenic purpura-hemolytic uremic syndrome. Transfusion 44(8):1149-1158

13. Esplin MS, Branch DW (1999) Diagnosis and management of thrombotic microangiopathies during pregnancy. Clin Obstet Gynecol 42(2):360-367

14. Allford SL, Hunt BJ, Rose P, Machin SJ (2003) Hemostasis and Thrombosis Task Force, British Committee for Standards in Hematology. Guidelines on the diagnosis and management of the thrombotic microangiopathic haemolytic anaemias. $\mathrm{Br} \mathrm{J}$ Haematol 120(4):556-573 